\title{
Most common HCV genotypes in patients from north-eastern Croatia
}

\author{
Magdalena Perić ${ }^{1}$, Zinka Bošnjak ${ }^{1}$, Snježana Džijan², Bojan Šarkanj ${ }^{3}$, Jerko Barbić ${ }^{2}$, \\ Ivana Roksandić Križan ${ }^{1}$, Nataša Ružman ${ }^{1}$, Vedran Bertić ${ }^{1}$, Dubravka Vuković ${ }^{1}$
}

${ }^{1}$ Institute of Public Health Osijek, Croatia ${ }^{2}$ Faculty of Medicine Osijek, Croatia

${ }^{3}$ Faculty of Food Technology, Croatia

\author{
Corresponding author: \\ Zinka Bošnjak \\ Institute of Public Health Osijek \\ F. Krežme 1, 31000 Osijek \\ Croatia \\ zinkahr@gmail.com \\ Tel.: + 38531225725 \\ Fax.: + 38531206807
}

Received: 17 September 2013

Accepted: 13 January 2014

Copyright (C) 2014 by

Academy of Sciences and Arts

of Bosnia and Herzegovina.

E-mail for permission to publish:

amabih@anubih.ba
Objective. The aims of this study were to determine the HCV-RNA viral load, genotype distribution, risk factors and symptoms of $\mathrm{HCV}$ RNA positive viral load in HCV antibody-positive patients from north-eastern Croatia. Materials and methods. From January 2009 to December 2011, $203 \mathrm{HCV}$ antibody- positive patients (130 men and 73 women; median age 44.5 years) were analyzed for HCV-RNA by the COBAS TaqMan HCV test and genotyped by the Linear Array HCV Genotyping test (both from Roche). All patients completed a structured questionnaire about risk factors and symptoms. Results. The HCV-RNA percentage was $61.1 \%$ and was similar for men and women. The HCV-RNA viral load increased with age: while $55 \%$ of 20-50 year old patients were HCV-RNA positive, $73 \%$ of patients $>50$ years were positive $(\mathrm{p}=0.021)$. Genotype 1 was the most prevalent genotype (79.8\%), followed by $3(12.9 \%), 4(6.5 \%)$, and $2(0.8 \%)$; genotypes 5 and 6 were not determined. Patients with genotype 1 (median, 50 years) were older than patients with 3 (median, 33.5 years) or 4 (median, 38 years). The blood transfusions performed in Croatian hospitals before 1993 was significantly associated with HCV-RNA positive viral load $(\mathrm{p}<0.05)$. Conclusion. These data indicated an elevated prevalence of genotype 1 in elderly HCV-RNA positive patients and it may continue to rise. Using RNA-based detection in HCV positive-antibody patients would allow early detection of HCV in the acute stage of HCV disease and the increased risk of HCV genotyperelated treatment failure.

Key words: HCV-RNA, HCV genotypes, HCV antibody-positive, Risk factors.

\section{Introduction}

Hepatitis $\mathrm{C}$ virus (HCV) was discovered in 1989 as the main cause of $90 \%$ of cases of after-transfusion hepatitis, previously known as 'non-A, non-B hepatitis'. According to the World Health Organization (WHO), HCV infection is a global health problem. It is estimated that 7.3-8.8 million people in Europe are infected with HCV (1.1-1.3\% of general population), leading to 86,000 deaths and 1.2 million of hospitalizations (1). Two hundred cases of acute and a similar number of chronic infections with hepatitis $\mathrm{C}$ virus $(\mathrm{HCV})$ are registered in Croatia every year. With an estimated $1.3 \%$ of HCV-positive persons in the general population, Croa- 
tia is one of the countries with a low HCV prevalence. Despite the legislation from 1992, which obliges all general practitioners to report infectious diseases to the Institute of Public Health (2), HCV screening and its epidemiological treatment have still not been regulated. For instance, a 2006 study from Zagreb reported that $78 \%$ of family members of infected individuals were not being monitored nor informed about HCV transmission risks (2). Moreover, high-risk individuals are not routinely surveyed for acute HCV infection.

Legislation has not included the regulation of epidemiological treatment of $\mathrm{HCV}$ infected individuals or their screening and informing them about all known $\mathrm{HCV}$ transmission risks, such as sexual intercourse, needle sharing among injection drug users etc. (3). It is not obligatory for Epidemiology Departments to monitor HCV-positive patients, but they do it through patient healthcare and contact tracing. After a certain period they test the sexual partners of the patient or those that are at greater risk of infection.

Contaminated blood is the main route for $\mathrm{HCV}$ transmission. Since the introduction of the obligatory testing of voluntary blood donors for anti-HCV antibodies in 1993, the spread of HCV through transfusions and hemodialysis has been almost completely eliminated in Croatia. However, intravenous drugs, sharing injection needles and tools for tattoos and body-piercing are today the most common modes of HCV transmission. Sexual transmission, organ transplantation, and invasive diagnostic and therapeutic approaches are additional risk factors for $\mathrm{HCV}$ infection. In fact, each hospitalization, even without transfusion, is a risk factor for $\mathrm{HCV}$ infection (4).

The currently used strategy for combating HCV infection in Croatia is a combined therapy with pegylated-interferon and ribavirin (PEG-INF/RBV). It is offered to in- dividuals with two successively increased alanine aminotransferase (ALT) levels, stage F2 liver fibrosis (according to Ishak), co-infection with hepatitis B virus (HBV), human immunodeficiency virus (HIV) or HCV genotypes 2 or 3, liver transplantation, and/or severe extra-hepatic symptoms. The success of this approach is however low in patients infected with the HCV genotype 1 , who respond inefficiently to therapy with PEG-INF/RBV and suffer from many adverse side effects (5). Moreover, due to the lack of routine screening of the highrisk population in our country, treatment of $\mathrm{HCV}$ infections begins at the chronic phase, which is more refractory to therapy and associated with an increased incidence of blood disorders, autoimmune disorders, skin conditions, and kidney disease (6). Finally, many chronic patients have normal levels of liver enzymes and do not receive therapy.

North-east Croatia has a higher mortality rate from chronic $\mathrm{HCV}$ infections than the rest of the country. Chronic infectionrelated death is the $15^{\text {th }}$ cause of death nationwide but the $10^{\text {th }}$ cause in our county ( 7 , $8)$. The reason for this remains elusive due to the limited data about HCV epidemiology in this region.

Therefore the aim of this study was to assess the genotype distribution, transmission risk factors, and symptoms of $\mathrm{HCV}$ infection in $203 \mathrm{HCV}$ antibody-positive individuals from several cities of the Osijek-Baranja County. Our results suggest that early detection of HCV-RNA in the acute stage of the disease and genotyping of HCV-RNA positive patients could offer more efficient therapies.

\section{Materials and methods}

\section{Study Population}

Between January 2009 and December 2011, we analyzed the plasma samples of $203 \mathrm{HCV}$ 
antibody-positive patients from north-eastern Croatia for HCV-RNA viral load (70.8\% of patients were from Osijek, 9.5\% were from Beli Manastir, 7.1\% were from Našice, $6.9 \%$ were from Đakovo, $4.7 \%$ were from Donji Miholjac, and $0.5 \%$ each were from Valpovo and Belišće), who were referred to our department by general practitioners or family doctors. Of 203 participants, 130 (63\%) were men and 73 (36\%) women. Their median age was 44.5 years (ages 22 to 82). All participants were informed about the protocol and study objective. Those who gave informed consent were interviewed by a structured questionnaire covering history of hemodialysis, surgical procedures, use of intravenous drugs, tattooing, unprotected sex, and suspected HCV symptoms, such as muscle pain and appetite loss.

\section{Blood Collection}

Blood samples were collected at the outpatient clinic of the Institute of Public Health of the Osijek-Baranja County. The blood was collected in $8.5 \mathrm{ml}$ PPT test-tubes (BD Plasma Preparation Tube, Becton Dickinson, Germany) containing a gel for plasma separation, and centrifuged for $10 \mathrm{~min}$ at 2,500 rpm/min (Hettich Rotanta $460 \mathrm{R}$, Germany) not later than 2 hours after collection. Blood samples were stored at $-20^{\circ} \mathrm{C}$ in a vertical position.

\section{Quantitative detection and genotyping of $\mathrm{HCV}$}

RNA was isolated from blood samples using the High Pure System Viral Nucleic Acid Kit (Roche Diagnostics, Mannheim, Germany) and quantified by the quantitative COBAS TaqMan HCV Test, v2.0 (Roche Diagnostics, Mannheim, Germany) using the COBAS TaqMan 48 instrument. The lower detection limit for HCV-RNA was 25 IU/ $\mathrm{ml}$. The HCV-positive plasma samples were further genotyped using the Amplicor HCV Specimen Preparation Kit, v 2.0 (Roche Diagnostics, Mannheim, Germany) and Linear Array Hepatitis C Virus Genotyping Test (Roche Diagnostics, Mannheim, Germany). All assays were performed according to the manufacturer's instructions.

\section{Statistical analysis}

The $\chi^{2}$ and Fisher's exact test, as appropriate, were used to compare percentage data (i.e., distribution of each risk factor between HCV-RNA positive and HCV-RNA negative patients). The Kruskal-Wallis test was used to compare continuous variables (i.e., the mean age between genotypes 1,2,3, and 4). Post-hoc analysis was performed by pairwise comparison of subgroups. Odds ratios (ORs) with 95\% confidence intervals (CIs) were calculated to show the strength and direction of associations. For all tests, $\mathrm{p}$ values $<0.05$ were considered statistically significant. Statistical analyses were performed using MedCalc (MedCalc Software version 10.2) and SAS.

\section{Ethical statement}

This study was approved by the Ethics Committee of the Institute of Public Health of Osijek-Baranja County (1346/09) and performed according to the ethical principles of the Helsinki declarations.

\section{Results}

\section{HCV-RNA distribution by age and sex}

HCV-RNA viral load was found in 124 (61.1\%) of $203 \mathrm{HCV}$ antibody-positive patients. Table 1 shows that the HCV-RNA viral load was found to be significantly higher $\left(\chi^{2}, \mathrm{p}=0.021\right)$ in patients older than 50 years (71.8\%) compared to $21-50$ year old HCVRNA positive patients (55.3\%). As shown in 
Table 1 Age and sex related distribution in HCV-RNA positive and negative patients

\begin{tabular}{|c|c|c|c|c|}
\hline \multirow{3}{*}{ Age and sex } & \multicolumn{2}{|l|}{ HCV-RNA } & \multirow{3}{*}{ OR $(95 \% \mathrm{Cl})^{*}$} & \multirow{3}{*}{$\mathrm{p}$ value } \\
\hline & HCV-RNA positive & HCV-RNA negative & & \\
\hline & n (\%) & n (\%) & & \\
\hline \multicolumn{5}{|l|}{ Age (years) } \\
\hline $21-50$ & $73(55.3)$ & $59(44.7)$ & $1.00 * *$ & \multirow{2}{*}{0.021} \\
\hline$>50$ & $51(71.8)$ & $20(27.2)$ & $2.06(1.11 ; 3.83)$ & \\
\hline \multicolumn{5}{|l|}{ Sex } \\
\hline Female & $43(58.9)$ & $30(41.1)$ & $1.00^{* * *}$ & \multirow{2}{*}{0.6332} \\
\hline Male & $81(62.3)$ & 49 (37.7) & $1.15(0.64 ; 2.07)$ & \\
\hline
\end{tabular}

*OR= odds ratio; $\mathrm{Cl}=$ confidence interval; ** Reference.

Table 1, there was no significant difference in the HCV-RNA positivity between women (58.9\%) and men (62.3\%).

\section{HCV genotype distribution}

Genotype 1 was the most prevalent (79.8\%), followed by 3 and 4 (12.9 and 6.5\%, respectively). Genotype 2 was the rarest genotype as it was detected in only one, 63-year old patient. Genotypes 5 and 6 were not detected (Figure 1).

While there was no significant genderrelated variation in the distribution of $\mathrm{HCV}$ genotypes, their age-related distribution differed (Figure 2).

We found a statistically significant difference between the distribution of genotypes

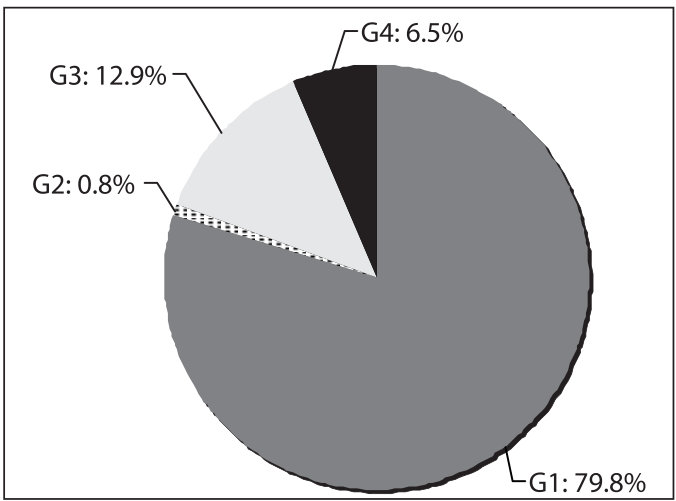

G=genotype.

Figure 1 Overall HCV genotype distribution. between the five age groups (Kruskal-Wallis ANOVA, $\mathrm{p}=0.0055$ ), with a mean rank of 67.81 for genotype 1, 112 for 2, 35.16 for 3 , and 45.25 for 4 . Post hoc analysis showed that the age-related distribution of genotype 3 infection significantly differed from 1 and $2(\mathrm{p}<0.05)$.

Figure 3 shows that the patients infected with genotype 1 have a higher tendency to be older (median age, 50 years) than those infected with 3 (median, 33.5 years) or 4 (median, 38 years). However, these differences in median age were not significant (Kruskal-Wallis, $\mathrm{p}=0.3679$ ).

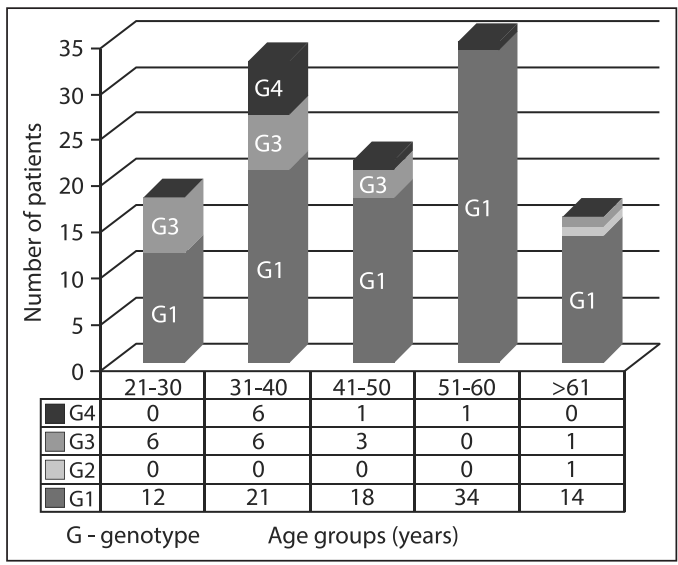

Figure 2 Age-specific distribution of HCV genotypes. The age-related difference between the genotype 1,3 , and 4 distributions was statistically significant $(p=0.0055$ by Kruskal-Wallis ANOVA). 


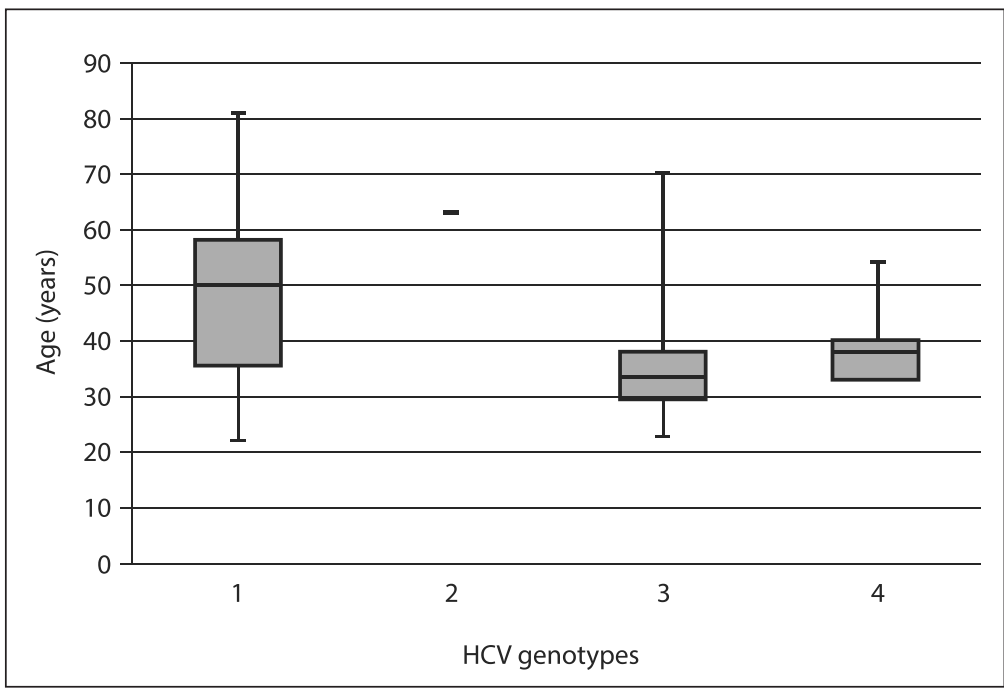

Figure 3 HCV genotype distribution by patient age.

\section{Risk factors and symptoms}

Table 2 summarizes the potential risk factors and HCV genotypes that were analyzed here. Univariate analysis showed that the independent predictor of HCV infection by genotype 1 in relation to infection by geno-

Table 2 Comparison of risk factors and HCV genotypes in 124 HCV-RNA positive patients

\begin{tabular}{|c|c|c|c|c|c|}
\hline \multirow{3}{*}{ Risk factors } & \multicolumn{5}{|c|}{ HCV genotypes } \\
\hline & 1 & 2 & 3 & 4 & $p$ value* \\
\hline & n (\%) & n (\%) & $\mathrm{n}(\%)$ & n (\%) & \\
\hline \multicolumn{6}{|c|}{ Surgery before 1993} \\
\hline Yes $(n=63)$ & $53(42.7)$ & $1(0.8)$ & $6(4.8)$ & $3(2.4)$ & \multirow{2}{*}{ NS } \\
\hline No $(n=61)$ & $46(37.1)$ & $0(0)$ & $10(8.1)$ & $5(4.1)$ & \\
\hline \multicolumn{6}{|c|}{ Blood transfusion before 1993} \\
\hline Yes $(n=48)$ & $44(35.5)$ & $1(0.8)$ & $3(2.4)$ & $0(0)$ & \multirow{2}{*}{0.010} \\
\hline No $(n=76)$ & $55(44.3)$ & $0(0)$ & $13(10.5)$ & $8(6.5)$ & \\
\hline \multicolumn{6}{|c|}{ Use of injection drugs } \\
\hline Yes $(n=35)$ & $24(19.3)$ & $0(0)$ & $8(6.5)$ & $3(2.4)$ & \multirow{2}{*}{ NS } \\
\hline No $(n=89)$ & $75(60.4)$ & $1(0.8)$ & $8(6.5)$ & $5(4.1)$ & \\
\hline \multicolumn{6}{|l|}{ Tattoo } \\
\hline Yes $(n=50)$ & $37(29.8)$ & $0(0)$ & $10(8.1)$ & $3(2.4)$ & \multirow{2}{*}{ NS } \\
\hline No $(n=74)$ & $62(50.0)$ & $1(0.8)$ & $6(4.8)$ & $5(4.1)$ & \\
\hline \multicolumn{6}{|l|}{ Muscle pain } \\
\hline Yes $(n=66)$ & $55(44.3)$ & $1(0.8)$ & $8(6.5)$ & $2(1.6)$ & \multirow{2}{*}{ NS } \\
\hline No $(n=58)$ & $44(35.5)$ & $0(0)$ & $8(6.5)$ & $6(4.8)$ & \\
\hline \multicolumn{6}{|l|}{ Appetite loss } \\
\hline Yes $(n=58)$ & $44(35.5)$ & $1(0.8)$ & $10(8.1)$ & $3(2.4)$ & \multirow{2}{*}{ NS } \\
\hline No $(n=66)$ & $55(44.3)$ & $0(0)$ & $6(4.8)$ & $5(4.1)$ & \\
\hline All patients & 99 (79.8) & $1(0.8)$ & $16(12.9)$ & $8(6.5)$ & \\
\hline
\end{tabular}

*Fisher's exact test; NS=Not statistically significant. 
types 2, 3 and 4 was a history of blood transfusion $(\mathrm{p}=0.010)$ if performed before 1993 . Other risk factors, including surgery before 1993, blood transfusion before 1993, drug use, tattoo, and two symptoms (muscle pain and appetite loss), did not significantly correlate with certain HCV genotype infection.

\section{Discussion}

Comprehensive epidemiological data on hepatitis $\mathrm{C}$ infection in HCV antibody-positive patients from north-eastern Croatia is limited. Only one study has so far analyzed the distribution of HCV genotypes in 111 infected patients from this region (9). The aim of our work was thus to assess the $\mathrm{HCV}$ genotype distribution for tailoring therapeutic modalities.

The HCV-RNA percentage in $\mathrm{HCV}$ antibody-positive patients in our community was $61.1 \%$ (124/203). Similar disparities in ratio between $\mathrm{HCV}$ antibody-positive and HCV-RNA viral load detectable plasma levels have been reported by others $(10,11)$.

Another important finding of this study is that older patients ( $>50$ years) suffered significantly more from HCV-RNA viral load than younger $(<50)$ ones, which is dissimilar to studies conducted in Brazil and the USA $(10,12)$. The reasons for this could be mainly because older patients had a greater probability of undergoing blood transfusions and surgery before 1993.

The distribution of $\mathrm{HCV}$ genotypes in north-eastern Croatia was similar to other European countries: genotype 1 was the most common type (79.8\%), followed by 3 (12.9\%), 4 (6.5\%) and 2 (0.8\%). Genotype 1 prevalence in our region was thus lower than in Romania (97.7\%), Hungary (94.5\%), Bulgaria (80.8\%) but higher than in Slovenia (79\%), Germany (70\%), Belgium (60\%), Serbia (57.6\%), Italy (57\%), and the Netherlands (49.3\%) (13-15). Genotype 1 was the most prevalent genotype in this study, similar to that in HCV-RNA positive patients from other European countries and worldwide $(16,17)$. Compared to our region, the lower prevalence of genotype 1 in HCV-RNA positive patients from western Europe may be due to earlier diagnosis of $\mathrm{HCV}$ infection.

The genotype 3 prevalence in HCV-RNA positive patients in Croatia appeared to be region-specific. While we found that its prevalence in north-eastern Croatia was relatively low (12.9\%), genotype 3 prevalence in western Croatia was much higher (43.7\%) (9). As the latter study included high-risk subjects residing in Split, a second-largest Croatian city with a large number of drug addicts, this may explain the difference between their and our results. Compared to other countries, the prevalence of genotype 3 in our study was higher than in Italy (5.9\%) but lower than in India (63\%) (17), Luxemburg (33\%), the Netherlands (29\%), Germany $(26 \%)(13,18)$ and Serbia $(21.2 \%)(15)$.

The prevalence of genotype 4 infection in HCV-RNA positive patients of north-eastern Croatia was low (6.5\%), similar to that in Serbia and Hungary (5\% each) but lower than in Belgium (15\%) and the Netherlands (11\%) (13-15). The higher genotype 4 prevalence in western Europe than in our region may be explained by the fact that genotype 4 has spread from central Africa and the Middle East to Europe by population migration (16, 19-20). Finally, the rarest HCV type in our community was genotype 2 . Its prevalence $(0.8 \%)$ was much lower than in other European countries: Italy $52.4 \%$ (21), the Netherlands 10\% (18), Belgium 5\% (13), Slovenia 5.2\% (22), and India 5.6\% (17). More studies with a higher number of HCV antibody-positive participants are necessary to confirm the rarity of genotype 2 infection in our community and to verify its putative correlation with increased age.

Another interesting finding of this study was that genotype 1 infections were more 
common in older patients, which is very similar to the findings in $\mathrm{HCV}$ infected patients in Vienna and the surrounding areas (23), due to two reasons: patients with genotypes 2 and 3 infection are more responsive to the standard combination of PEG-INF/ RBV therapy compared to genotype 1 infection, and the most HCV infections through blood transfusion are caused by $1(14,18$, 23). Carrion et al. (24) found that the prevalence rate of genotype 1 increased with age amongst the European population. In contrast, genotype 3 and $4 \mathrm{HCV}$ infections were common in younger patients. This could be caused by several factors: firstly, the higher level of risky behavior of genotype 3-infected patients. They were significantly more frequently injection drug users than those infected with genotype 1 (50 vs. $24 \%$, respectively, $\mathrm{p}=0.0374)$. A similar correlation between intravenous drug use and genotype 3 infections was reported previously. Secondly, genotype 4 infections spread by migration, which may explain why these infections were more common in younger patients (25-27). Thirdly, genotype 1 infections are more refractory to PEG-INF/RBV (23) and may thus remain detectable in older $\mathrm{HCV}$ infected patients.

Blood transfusion, intravenous drug use, tattooing, and body-piercing have been the main routes of HCV transmission (28). We found blood transfusion before 1993 as a risk factor significantly associated with $\mathrm{HCV}$ infection. This is not surprising since the obligatory analysis of donated blood for anti-HCV antibodies in Croatia began in 1993. Similar findings were reported in Central Africa (29), Brazil (10) and Jordan (30). Unexpectedly, however, factors such as intravenous drug usage and tattooing did not significantly associate with HCV infection in north-eastern Croatia, contrary to data from other studies (31-33). Whether this is due to the small number of participants in our study remains to be elucidated.

\section{Conclusion}

In conclusion, despite some limitations (the low number of participants and missing epidemiological evidence about their age at the time of infection and administered therapy), this study was the first to indicate that the majority of HCV-RNA positive patients in north-eastern Croatia were infected with genotype 1. Moreover, it demonstrated that the prevalence of genotype 1 was more pronounced in individuals older than 50 than in other Croatian regions. Due to the aging trend of our community, we might experience a rise in the incidence of genotype 1 infections, especially in individuals with a history of transfusion before 1993. Due to the refractory nature of genotype 1 infection to the PEG-INF/RBV, the financial burden related to its medical treatment might thus surpass the current 19,000 Euro/year (Clinical Health Center Osijek). Routine HCVRNA-based screenings of high-risk individuals (such as injection drug users, young people with numerous tattoos and/or bodypiercing, dialyzed or immunosuppressed patients) would help in the earlier detection of acute stage HCV infections in our community. In addition, HCV genotyping and more efficient therapies for genotype 1 infections, i.e. with protease inhibitors and PEG-INF/ RBV therapy $(34,35)$, would help in diminishing the HCV-related medical costs.

Acknowledgments: The authors would like to thank all participants in our study. The authors also greatly appreciate the help received from Dr Marcela Čović for data analysis and article revision.

Authors' contributions: Conception and design: MP, $\mathrm{ZB}, \mathrm{DV}$; Acquisition, analysis and interpretation of data: BŠ, SDž; Drafting the article: NR, IRK; Revising it critically for important intellectual content: VB, JB.

Conflict of interest: The authors declare that they have no conflict of interest. 


\section{References}

1. Mühlberger N, Schwarzer R, Lettmeier B, Sroczynski G, Zeuzem S, Siebert U. HCV-related burden of disease in Europe: a systematic assessment of incidence, prevalence, morbidity, and mortality. BMC Public Health. 2009;9:34.

2. Kosanović ML, Knežević J. Epiemiological Characteristics of Individuals Tested for Hepatitis C at Zagreb Institute of Public Health [In Croatian]. HČJZ; 2006;2(8):1-3.

3. Ministry of Health and Social Care of the Republic of Craotia. Law of the Protection of the population from Infectious Diseases [In Croatian]; 1992 (NN 60/92).

4. Sun CA, Chen HC, Lu CF, You SL, Mau YC, Ho MS, et al. Transmission of hepatitis $\mathrm{C}$ virus in Taiwan: prevalence and risk factors based on a nationwide survey. J Med Virol. 1999;59(3):290-6.

5. Fried MW, Shiffman ML, Reddy KR, Smith C, Marinos G, Gonçales FL Jr, et al. Peginterferon alfa-2a plus ribavirin for chronic hepatitis $\mathrm{C}$ virus infection. N Engl J Med. 2002;347(13):975-82.

6. Ko HM, Hernandez-Prera JC, Zhu H, Dikman SH, Sidhu HK, Ward SC, et al. Morphologic Features of Extrahepatic Manifestation s of Hepatitis C Virus Infection. Clin Dev Immunol. 2012;2012:740138-47.

7. Croatian National Institute for Public Health, Croatian National Cancer Registry. Cancer Incidence in Croatia, 2011 [cited 2013 Feb 27]. Available from: http://www.hzjz.hr/cancer/annual_rep. htm.

8. Santo T, Samardžić S, Kraljik N. Assessment of health and social conditions in the Osijek-baranja County [In Croatian]. HČJZ 2008;(15):19-34.

9. Vince A, Iscić-Bes J, Zidovec Lepej S, BaćaVrakela I, Bradarić N, Kurelac I, et al. Distribution of hepatitis $C$ virus genotypes in Croatia-a 10 year retrospective study of four geographic regions. Coll Antropol. 2006;30(Suppl 2):139-43.

10. Bezerra CS, Lima JMC, Vilar JL, Moreira JLB, Frota CC. Viral hepatitis C in leading Brazilian hospital: epidemiological factors and genotyping. Braz J Microbiol. 2007;38(4):656-61.

11. Silva LK, Paraná R, Souza S, Berby F, Kay A, Trepó $\mathrm{C}$, et al. Hepatitis $\mathrm{C}$ virus genotypes in a northeastern area of Brazil. Am J Trop Med Hyg. 2000;62(2):257-60.

12. Williams IT, Bell BP, Kuhner W, Alter MJ. Incidence and Transmission Patterns of Acute Hepatitis C in the United Sates, 1982-2006. Arch Intern Med. 2011;171(3):242-8.

13. de Vries MJ, te Rijdt B, van Nieuwkerk CM. Genotype distribution amongst hepatitis $\mathrm{C}$ patients in the Netherlands. Neth J Med. 2006;64(4):109-13.
14. Grigorescu M. HCV genotype 1 is almost exclusively present in Romanian patients with chronic hepatitis C. J Gastrointestin Liver Dis. 2009;18(1):45-50.

15. Stamenković G, Zerjav S, Veličkovic ZM, Krtolica K, Samardžija VL, Jemuović L, et al. Distribution of HCV genotypes among risk groups in Serbia. Eur J Epidemiol. 2000;16(10):949-54.

16. Zaltron S, Spinetti A, Biasi L, Baiguera C, Castelli F. Chronic HCV infection: epidemiological and clinical relevance. BMC Infect Dis. 2012;12(Suppl 2):S2.

17. Charkavarati A, Dogra G, Verna V, Srivastrava AP. Distribution pattern of $\mathrm{HCV}$ genotypes \& its association with viral load. Indian J Med Res. 2011;133(3):326-31.

18. Roman F, Hawotte K, Struck D, Ternes AM, Servais JY, Arendt V, et al. Hepatitis $\mathrm{C}$ virus genotypes distribution and transmission risk factors in Luxembourg from 1991 to 2006 . World J Gastroenterol. 2008;14(8):1237-43.

19. Echevarrìa JM, León P, Pozo F, Avellón A. Followup of the prevalence of hepatitis $C$ virus genotypes in Spain during a nine-year period (1996-2004). Enferm Infecc Microbiol Clin. 2006;24(1):20-5.

20. Kabir A, Seyed-Moayed A, Hussein K. Distribution of hepatitis $C$ virus genotypes in patients infected by different sources and its correlation with clinical and virological parameters: a preliminary study. Comp Hepatol. 2006;5:4-9.

21. Adinolfi LE, Utili R, Tripodi MF, Rosario P, Mormone G, Ragone E, et al. Relationship between genotypes of the hepatitis $\mathrm{C}$ virus and histopathological manifestations in chronic hepatitis C patients. Eur J Gastroenterol Hepatol. 2000;12(3):299-304.

22. Seme K, Vrhovac T, Močilnik M, Lešničar G, Baklan Z, Volkar JM, et al. Hepatitis C virus genotypes in 1,504 patients in Slovenia, 1993-2007. J Med Virol. 2009;81(4):634-9.

23. Haushofer AC, Kopty C, Hauer R, Brunner H, Halbmayer WM. HCV genotypes and age distribution in patients of Vienna and surrounding areas. J Clin Virol. 2001;20:41-7.

24. Carrion AF, Martin P. Viral hepatitis in the Elderly. Am J Gastroenterol. 2012;107(5):691-7.

25. Ansaldi F, Bruzzone B, Salmaso S, Rota MC, Durando P, Gasparini R, et al. Different seroprevalence and molecular epidemiology patterns of hepatitis $\mathrm{C}$ virus infection in Italy. J Med Virol. 2005;76(3):327-32.

26. Ramia S, Eid-Fares J. Distribution of hepatitis C virus genotypes in the Middle East. Int J Infect Dis. 2006;10(4):272-7. 
27. Shustov AV, Kochneva GV, Sivolobova GF, Grazhdantseva AA, Gavrilova IV, Akinfeeva LA, et al. Molecular epidemiology of the hepatitis $C$ virus in Western Siberia. J Med Virol. 2005;77(3):382-9.

28. Zumaeta Villena E. Transmission routes of hepatitis C virus infection. Ann Hepatol. 2006;5(1):12-4.

29. Njouom R, Caron M, Besson G, Ndong-Atome GR, Makuwa M, Pouillot R, et al. Phylogeography, risk factors and genetic history of hepatitis $\mathrm{C}$ virus in Gabon, central Africa. PloS One. 2012;7(8):e42002.

30. Bdour $\mathrm{S}$. Hepatitis $\mathrm{C}$ virus infection in Jordanian haemodialysis units: serological diagnosis and Genotyping. J Med Microbiol. 2002;51:700-4.

31. Carney K, Dhalla S, Aytaman A, Tenner CT, Francois F. Association of tattooing and hepatitis $\mathrm{C}$ virus infection: a multicenter case-control study. Hepatology. 2013;57(6):2117-23.

32. Makkai T, McAllister I. Prevalence of tattooing and body piercing in the Australian community. Commun Dis Intell Q Rep. 2001;25(2):67-72.

33. Sy T, Jamal MM. Epidemiology of hepatitis $C$ virus (HCV) infection. Int J Med Sci. 2006;3(2):41-6.

34. Bacon BR, Gordon SC, Lawitz E, Marcellin P, Vierling JM, Zeuzem S, et al. Bocepravir for Previosly Treated Chronic HCV Genotype 1 Infection. N Engl J Med. 2011;364(13):1207-17.

35. Calle Serrano B, Manns MP. HCV's days are numbered: next-generation direct-acting antivirals and host-targeting agents. Antivir Ther. 2012;17(6 Pt B):1133-46. 